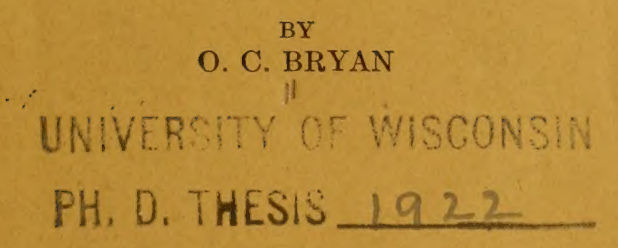

Wisconsin Agricultural Experiment Station 
$\therefore \therefore$ 


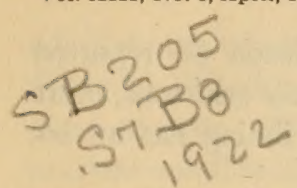

\title{
EFFECT OF DIFFERENT REACTIONS ON THE GROWTH AND NODULE FORMATION OF SOYBEANS ${ }^{1}$
}

\author{
O. C. BRYAN
}

Wisconsin Agricultural Experiment Station

Received for publication July 20,1921

Although it is well known that soil acidity and alkalinity have a marked effect on cultivated plants, especially certain legumes, yet, it has never been definitely determined at what reaction the legumes grow best and become inoculated most abundantly. Whether the favorable range of reaction is wide or narrow, and what this range is for each of the legumes are very important questions from both a practical and a scientific standpoint. In order to gain further information on these questions, the present investigation was undertaken.

The soybean was used in the beginning because of its adaptation to water cultures and because of its importance as a crop. Several different strains of soybean bacteria were studied. For comparison, some results with corn and cowpeas obtained under similar conditions are reported herein.

An exhaustive discussion of the literature on this subject does not seem necessary and only a brief review of some of the more important papers is given. The magnitude of the hydrogen- and hydroxyl- ion concentration of a number of soil solutions and suspensions have recently been determined by Gillespie (15), Sharp and Hoagland (35), Plummer (32), Truog (37), and others. These investigations have shown that soil solutions have a wide range of reactions, namely, from $\mathrm{pH} 3$ to $\mathrm{pH} 9$.

The importance of the effect of the soil reaction on the soil bacteria is well recognized. Gruzit (14) reported that an alkaline reaction was more favorable for the growth of the bacteria than an acid, or even neutral reaction. Salter (33) reported that red clover bacteria do best at a neutral or slightly acid reaction while the alfalfa bacteria do best at a slightly alkaline reaction. Fred and Loomis (11) reported that an alkaline reaction $(\mathrm{pH} 7.72)$ produced maximum growth of the alfalfa bacteria. Fred and Davenport (12) reported that a correlation exists between the acid resistance of the nodule bacteria and the

${ }^{1}$ Part I of a thesis submitted at the University of Wisconsin in partial fulfillment of the requirements for the degree of Doctor of Philosophy.

Published with the permission of the Director of the Wisconsin Agricultural Experiment Station.

The writer wishes to express his appreciation for the helpful suggestions and criticisms tendered by Professors E. Truog and E. B. Fred under whose direction the work has been done. 
acid resistance of the higher plants. Bewley and Hutchinson (2) reported that some of the legume bacteria are either killed in definitely acid soils, or at least lose their activity, while Hiltner (21) claimed that liming has an injurious effect on lupine bacteria.

The sensitiveness of plants to the reaction of dilute solutions of acids,bases and salts was noted by Kahlenberg and True (26), Heald (20) and Loew (29). These investigators studied primarily the direct chemical effect of reaction on seedlings and not the influence on growth, and hence did not use balanced nutrient solutions. Because of this condition definite conclusions can not be drawn from their data regarding influence on growth. Their data show, however, that seedlings differ widely in their behavior toward reaction.

Cameron and Breazeale (4) reported that corn was much more acid tolerant than wheat or clover. Hartwell and Pember (18) claimed that some of the cereals are more sensitive to acidity than others but no statement was made as to the relative sensitiveness. Hoagland (23) reported that barley seedlings grew better in a slighty acid reaction than in a neutral or alkaline reaction. This was also reported by Salter and McIlvane (34) in working with corn, wheat, soybeans and alfalfa. The data of the latter indicate that alfalfa is more sensitive to acidity than corn, wheat or soybeans. Joffe (25) reported that alfalfa produced good growth in soil cultures which were made very acid ( $\mathrm{pH} 3.8$ ) by the addition of sulfuric acid. Hixon (22) noted that there was a difference in water content, organic matter, and total ash in the roots of 16-day-old wheat seedlings grown at different reactions.

Hartwell and Pember (18) and Dachnowski (10) claimed that the hydrogen ion was more toxic to plant growth than the hydroxyl ion. This question was investigated by Hoagland (23) who reported the opposite results with barley seedlings. These contradictory results are possibly due to different methods of determining the reactions. Whether total acidity or hydrogen ion concentration is used as a criterion for indicating reactions is of great importance. Other factors, e. g., kind of nutrient solution used and proper maintenance of the desired reaction, are also important.

The change in reaction of the nutrient solution in contact with growing plant roots was noticed by Hartwell and Pember (18) who reported that an acid solution tended to become alkaline. This was also reported by Breazeale and LeClerc (3) who claimed from their work with wheat seedlings that the change in reaction of the nutrient solution was due to the selective absorption of the ions by the plants. The buffer condition of the nutrient solution and the frequency of renewing the solution are no doubt important factors in maintaining a constant reaction. The change in reaction of the nutrient solution in contact with plant roots during 1-day periods was found by Hoagland (23) to be quite considerable provided the initial reaction was not favorable.

Salter and McIlvane's (34) results indicate that their nutrient solution remained fairly constant over a period of 4 days when in contact with growing plants. Duggar (9) concluded that, in general, an acid or an alkaline

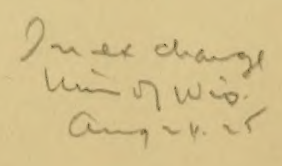


solution tended toward neutrality when in contact with growing plants. However, this change depended on the nutrient solution used and the rate of plant growth. The most favorable reaction also varied with the. kind of nutrient solution used.

In connection with the influence of reaction on plant growth, it is well to mention the toxic effects of soluble aluminum salts as reported by several investigators. Abbott, Conner and Smalley (1) reported that the toxic effect of aluminum nitrate was about the same as a solution of nitric acid of equal normality; and that water extracts from acid soils containing soluble aluminum salts were as toxic to plant growth as a nutrient solution containing an equal amount of aluminum salts. Hartwell and Pember (19) found that aluminum salts were considerably more toxic to barley seedlings than to rye seedlings. The toxic effect of acidity alone was about the same on both plants. They concluded that lime may precipitate the aluminum and thus be of value in this way as well as in neutralizing the acidity. Mirasol (30) reported that aluminum salts which could be extracted from the soil with a solution of potassium nitrate were probably the cause of the unproductiveness of three acid soils of Illinois. Conner (6) reported that much of the harmful effects of acidity of soils is due to soluble aluminum salts; and the presence of abundant lime or phosphate will prevent this harmful effect. He noted that some plants are more sensitive to aluminum salts than others. This condition was also noted by Hartwell.

Undoubtedly, in very acid soils aluminum, manganese and other toxic substances go into solution and produce injurious effects on cultivated plants.

The results of the various investigations may be summarized as follows: The range of reaction of different soils is sufficiently wide to give conditions of acidity and alkalinity in some cases which are unfavorable to bacteria and higher plants. The different legume bacteria vary in their behavior toward reaction, and the degree of the acid resistance appears to be in the same direction as that of the host plants. In the case of plants, there are some contradictory results, but, in general, they indicate that plants differ in their behavior toward reaction. This is in line with field observations. In studying a problem of this nature, there are a number of factors which are difficult to control and the conflicting results obtained by the different investigators are perhaps due in part to the difficulty of controlling the reactions, and in some cases to the use of unfavorable nutrient solutions.

In regard to the toxic effects of soluble aluminum and other substances in acid soils, it appears that plants vary in their behavior toward these toxic substances and that the harmful effects of acidity in some soils are due in part to soluble aluminum salts.

GROWTH OF DIFFERENT STRAINS OF SOYBEAN BACTERIA AT VARIED REACTIONS

Since some investigators (2) had noted that many of the legume bacteria are either killed, or, at least rendered inactive in acid soils, it was thought best, as 
a preliminary experiment, to determine the critical hydrogen- ion concentration of the various strains of soybean bacteria in pure cultures and also to determine if there is any marked difference in behavior of these strains of bacteria at different reactions. By strains of bacteria, is meant a pure culture isolated from a known variety of soybeans.

Twenty-one ${ }^{2}$ strains of soybean bacteria were grown on mannit, on sucrose and on soil-extract agars. The mannit and sucrose agars were prepared according to Ashby's formula as follows:

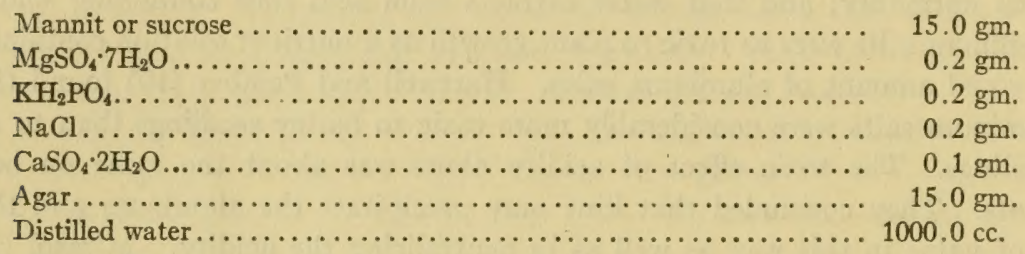

The soil extract agar was prepared by diluting $100 \mathrm{cc}$. of soil extract from a silt loam soil to $1000 \mathrm{cc}$. and adding $15 \mathrm{gm}$. each of mannit and agar. The range of reaction used was from $\mathrm{pH} 3.3$ to $\mathrm{pH} 10$ with the sucrose agar and from $\mathrm{pH} 3.3$ to $\mathrm{pH} 7$ with the mannit and soil extract agars. The desired reactions were obtained by adding varied amounts of sterile sulfuric acid and sodium hydroxide, as the case required, before the media were allowed to solidify in slants. The Clark and Lub's method for colorimetric determination of the reactions of solutions was employed. Each culture was inoculated with one drop of suspension containing the bacteria. Triplicates of each reaction were used in all cases. The cultures were incubated 15 to 20 days at $28^{\circ} \mathrm{C}$. before final results were recorded.

In general the mannit and soil extract agars showed a more vigorous growth than the sucrose agar, although the three media showed only minor differences in critical $\mathrm{pH}$ for the various strains of bacteria. There were small differences in growth of bacteria between the reactions $\mathrm{pH} 7$ and $\mathrm{pH} 6.5$ but an increase in hydrogen-ion concentration from $\mathrm{pH} 6.5$ to the critical concentration produced a gradual decrease in growth with each strain of bacteria. Eight strains of the bacteria were grown in the alkaline range, all of which grew at $\mathrm{pH} 10$. The maximum growth of the eight strains grown in the alkaline range took place at reaction of about 7.6. Table 1 gives the critical hydrogen-ion concentration for the different strains of soybean bacteria studied. By critical hydrogen-ion concentration is meant the reaction at which the bacteria do not produce any visible growth during the 15 days after inoculation. It will be noted that there is not a great difference in the critical hydrogen-ion concentration for the various strains of soybean bacteria.

${ }^{2}$ Fourteen of the different strains of soybean bacteria studied were furnished through the kindness of the Bureau of Plant Industry, of the United States Department of Agriculture One strain was furnished through the kindness of Dr. A. L. Whiting, University of Illinois. 
TABLE 1

The critical hydrogen-ion concentration for soybean bacleria on mannit, sucrose, and soil extract agar

\begin{tabular}{|c|c|c|}
\hline STRAIN OF BACTERIA & NUMBER & CRitical pH Value \\
\hline Arlington...... & 118 & 4.2 \\
\hline 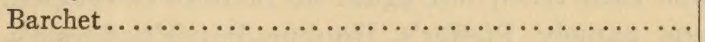 & 293 & 4.2 \\
\hline Barchet $\ldots \ldots \ldots \ldots \ldots \ldots \ldots \ldots \ldots \ldots \ldots \ldots \ldots \ldots$ & 218 & 4.6 \\
\hline 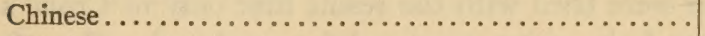 & 271 & 4.6 \\
\hline Cloud..$\ldots \ldots \ldots \ldots \ldots \ldots \ldots \ldots \ldots \ldots \ldots \ldots \ldots \ldots \ldots \ldots \ldots \ldots$ & 270 & 4.2 \\
\hline 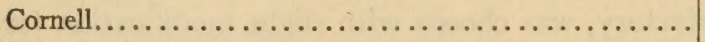 & 150 & 4.5 \\
\hline 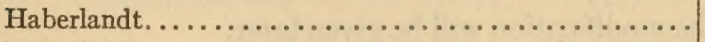 & 210 & 4.0 \\
\hline 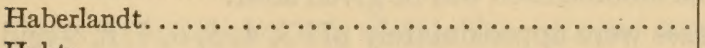 & 334 & 4.0 \\
\hline Hobta..................................... & 337 & 4.0 \\
\hline 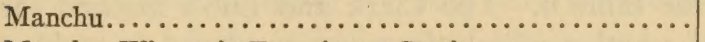 & 312 & 4.7 \\
\hline Manchu, Wisconsin Experiment Station............. & 154 & 4.6 \\
\hline Medium early, Illinois Experiment Station........... & & 4.0 \\
\hline 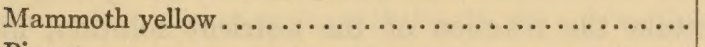 & 338 & 4.2 \\
\hline 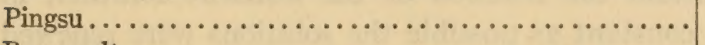 & 275 & 4.2 \\
\hline Roosevelt................................... & , 181 & 4.6 \\
\hline Roosevelt................................... & 187 & 4.0 \\
\hline 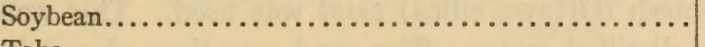 & 152 & 4.6 \\
\hline 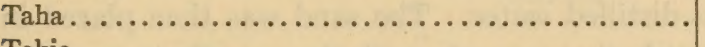 & 233 & 4.4 \\
\hline 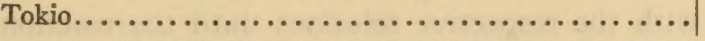 & 256 & 4.6 \\
\hline
\end{tabular}

PLANT CULTURES

\section{Methods}

The plants were grown in solution and sand cultures in the greenhouse from March 1 to July 25. The culture vessels used were 500 and 600-cc. percolators. These were provided with glass tubes and pinch-cocks at the bottom in order that the solutions might be easily removed without disturbing the plants. In the case of sand cultures, the percolators were supported by iron |ring stands and wrapped in heavy brown paper to exclude the light. Those containing solution cultures of soybeans were placed in boxes and surrounded with moist sawdust to exclude light and prevent rapid changes of temperature. The glass tubes extended through holes in the boxes in order that the solutions might be removed readily. A few solution cultures of corn and cowpeas were also set up. For holding these percolators, circular holes were cut of such size in the top of a greenhouse bench that the percolators passed through to the rim around the mouth which acted as a support. The light was excluded from beneath the bench.

The most desirable nutrient solution for this type of investigation was unknown at the start. A modified form of Shive's three-salt solution was first used with the soybeans. The modification consisted in reducing the amount of $\mathrm{Ca}\left(\mathrm{NO}_{3}\right)_{2}$ to one-fourth that recommended by Shive, and adding an equal amount of $\mathrm{CaCl}_{2}$. This made a total reduction of calcium to about one-half 
that in the regular solution. The chloride was substituted for the nitrate, since large quantities of nitrates are known to hinder nodule formation. The reduction of calcium was made to reduce the precipitation of $\mathrm{Ca}_{3}\left(\mathrm{PO}_{4}\right)_{2}$ in the alkaline solutions. This modified solution proved unfavorable for nodule formation of soybeans in solution cultures. Shive's regular solution with varied amounts of nitrates was then tried, but again no nodules developed. Several other nutrient solutions, namely, Pfeffer's, Hopkins-Pettit's, Crone's, and also Mendota Lake water were tried with the result that only in Crone's nutrient solution and Mendota Lake water were nodules produced. Crone's solution being the most satisfactory, was chosen with slight modification for the work reported herein. The modification will be given later.

The reactions used in all cases were approximately $\mathrm{pH} 3,4,5,6,7,8,9$ and 10. For specific reactions, see table 6 . The Clark and Lub's method for colorimetric determination of reaction of solutions was employed in making the adjustments. The standards were checked at intervals with the hydrogen electrode. In order to maintain the reaction of the nutrient solution, in contact with plant roots, as constant as possible the solutions were renewed daily.

For the sand cultures, 20-mesh (Ottawa silica) sand was used. This was first thoroughly washed with distilled water. The sand was then placed in the percolators and washed with the respective solutions until the reaction remained constant on passing through the sand. The solution in sand cultures as in solution cultures were renewed daily. This was done by means of suction as sugested by McCall (31). The percolators were ideally adapted for changing of solutions.

The seeds were germinated in clean quartz sand and allowed to grow 3 to 5 days before being transferred to the percolators. Two seedlings were grown in each percolator both in sand and solution cultures. The seedlings, in case of the solution cultures, were held in place by means of paraffined corks and plugs of cotton. In order that the seedlings would not be subjected to a great change in reaction at once when being transferred to the percolators, the acid and alkaline reactions of the nutrient solution were brought to the desired points gradually over a period of 2 days. The solutions were inoculated 3 days after the seedlings had been transferred to the percolators. This was done by placing the inoculum in the nutrient solutions at the time the solutions were renewed. The plant cultures were grown for 25 to 35 days.

\section{Growth of soybeans in Shive's nutrient solution at different reactions}

As previously stated, a modified form of Shive's nutrient solution was first used in both sand and solution cultures. It was prepared from the following stock solutions in which the amounts of salts are indicated on the anhydrous basis. 


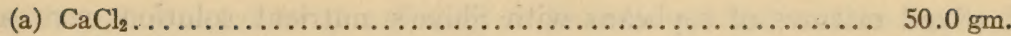

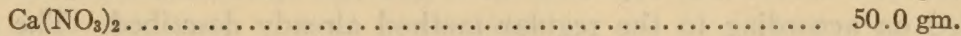

Distilled water............................... $500.0 \mathrm{cc}$.

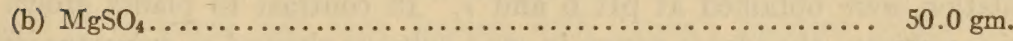

Distilled water.............................. $500.0 \mathrm{cc}$.

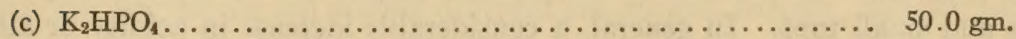

Distilled water................................ $500.0 \mathrm{cc}$

(d) $\mathrm{FeCl}_{3} \ldots \ldots \ldots \ldots \ldots \ldots \ldots \ldots \ldots \ldots \ldots \ldots \ldots \ldots \ldots \ldots \ldots \ldots \ldots \ldots \ldots, 2.5 \mathrm{gm}$.

Distilled water............................... $300.0 \mathrm{cc}$.

Ten cubic centimeters of (a), (b), (c), and ten drops of (d) were added to 4 liters of distilled water. Dilute sulfuric acid or sodium hydroxide was added to portions of this solution until the desired reactions were obtained. The general method of procedure already outlined was followed. The plants were allowed to remain in the solution 24 days from time of inoculation.

TABLE 2

Growth and inoculation of soybeans in sand cultures with Shive's nutrient solution at different reactions

\begin{tabular}{|c|c|c|}
\hline REACTION OF CULTURE & NODULES PER PLANT & PLANT DEVELOPAENT \\
\hline$p H$ & & \\
\hline 3.2 & 0 & Tops fair \\
\hline & & Roots dark and stubby \\
\hline 4.2 & 5 & Roots better than at $\mathrm{pH} 3.2$ \\
\hline 5.0 & 12 & Tops good \\
\hline 6.0 & 35 & $\begin{array}{l}\text { Roots slightly dark } \\
\text { Tops good } \\
\text { Roots good }\end{array}$ \\
\hline 6.9 & 49 & $\begin{array}{l}\text { Tops good } \\
\text { Roots good }\end{array}$ \\
\hline 8.0 & 11 & $\begin{array}{l}\text { Tops good } \\
\text { Roots slightly brown }\end{array}$ \\
\hline 9.0 & 2 & $\begin{array}{l}\text { Tops small } \\
\text { Roots very brown }\end{array}$ \\
\hline 9.9 & 0 & Very poor \\
\hline
\end{tabular}

The results of all plants in all experiments at different reactions will be referred to as at $\mathrm{pH} 3,4,5,6,7,8,9$, and 10 although the actual $\mathrm{pH}$ value may have been slightly more or less. For specific reaction with Shive's nutrient solution, see table 2 .

Only two nodules developed in Shive's nutrient solution and these appeared at $\mathrm{pH}$ 8. A poor and injured condition of the plants indicated that something was wrong with the nutrient solution. This may have been due to the presence of toxic impurities in the salts used. Plants at $\mathrm{pH} \mathrm{3,4}$ and 10 were almost 
dead. Sand cultures of soybeans with Shive's nutrient solution were also carried on according to the regular method already described. The results of growth and inoculation with these are given in table 2. The best growth and inoculation were obtained at $\mathrm{pH} 6$ and 7. In contrast to plants grown in solution cultures, the plants grown in sand cultures showed no injurious effect other than that due to reaction. The plants at $\mathrm{pH} 3,4$ and 10 had very dark roots and small tops. In general, a considerable increase in acidity or alkalinity caused a decrease in plant growth. Perhaps the absence of injurious effects in the sand cultures was due to adsorption of toxic substances from the solution by the sand.

\section{The effect of nitrates on nodule formation in Shive's mutrient solution}

Since practically no nodules developed in solution cultures with Shive's solution, it was thought that possibly the presence of nitrates prohibited inoculation. To determine the influence of nitrates on nodule formation, soybeans were grown in Shive's nutrient solutions containing $2,1, \frac{1}{2}, \frac{1}{4}, \frac{1}{8}, \frac{1}{16}$, $\frac{1}{36}$, and $\frac{1}{64}$ times the usual amount of nitrates recommended by Shive, and also in one solution entirely without nitrates.

For culture vessels, 500-cc. wide-mouthed bottles were used, and two soybean seedlings which had been germinated in clean quartz sand were placed in each. The seedlings were held in place with paraffined corks and plugs of cotton. The solutions were inoculated and renewed weekly. The plants were allowed to grow for four weeks, during which time not a single plant in any of the solutions developed any nodules. All the plants had yellowish leaves and somewhat dark and stubby roots indicating that the solution was toxic.

\section{Influence of different mutrient solutions on nodule formation of soybeans}

Since all attempts to get nodule formation on soybeans in solution cultures had practically failed, it was decided to determine the effects of different nutrient solutions on inoculation of soybeans. In addition to Shive's solution, Hopkin-Pettit's, Pfeffer's and Crone's solution, and also Mendota Lake water were used. The cultures were carried on in exactly the same manner as the previous ones. At the end of 4 weeks, the plants in Crone's nutrient solution and Mendota Lake water had developed a goodly number of nodules and the plant growth was healthy. Those in Shive's nutrient solution had developed only two nodules and the roots were dark and stubby, and those in the other two solutions did not develop any nodules at all. Their leaves were also yellowish and the roots dark. Plate 1 shows the root development and nodule formation in the different solutions. 


\section{Growth and inoculation of soybeans in Crone's mutrient solution at different reactions}

The principal experiment on the influence of reaction on growth and inoculation of soybeans was next started with Crone's nutrient solution. The buffer condition of this solution was, however, unsatisfactory in the alkaline range and for this reason several different substances, namely, di-basic sodium phosphate, di-basic potassium phosphate, sodium glycero phosphate, and sodium carbonate and bicarbonate were added and tested for their buffer effect, and also influence on nodule formation. Of these, sodium carbonate at the rate of $\frac{3}{4} \mathrm{gm}$. per liter proved to be the most satisfactory, and hence was used. The salts for Crone's solution were ground to a fine powder and thoroughly mixed in the following proportions.

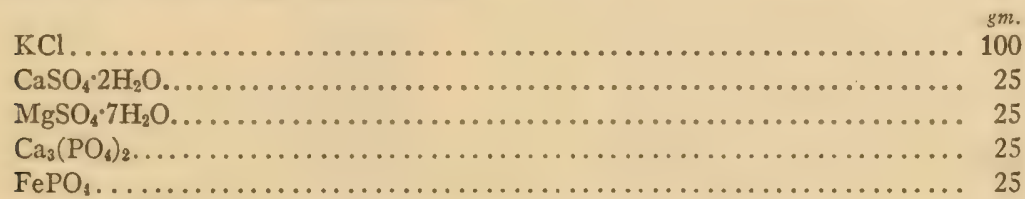

For the solution, $12 \mathrm{gm}$. of this mixture were added to 8 liters of distilled water. The mixture was well shaken with the water and left to stand for one day, at end of which time the solution was filtered to remove the insoluble materials. The acid reactions were obtained by adding varied amounts of sulfuric acid. The alkaline reactions were obtained by first adding the sodium carbonate and then acid until the desired reaction existed.

The plants were grown in percolators according to the general method already outlined. Good plant growth took place at the favorable reactions. In all cases duplicates agreed as to nodule formation and root development. Plate 2 serves to indicate the relative size of plants and nodules per plants in solution cultures. It will be noted from plates 3 to 10 , inclusive, that plants at $\mathrm{pH} \mathrm{3,4}$ and 10 had no nodules. Plants at $\mathrm{pH} 4.5$ which is not given in figure 2 developed a few nodules, but at this reaction the roots were dark and stubby. Plants at $\mathrm{pH} 5$ had fair inoculation. The tops of the plants at this reaction were as tall as those at $\mathrm{pH} 6$, but were yellow and much less vigorous. Plants at $\mathrm{pH} 6$ and 7 were decidedly the best, both as to growth and inoculation. Those at $\mathrm{pH} 6$ were perhaps a trifle better than those at $\mathrm{pH} 7$. Plants at $\mathrm{pH} S$ had some nodules but the roots were slightly brown. The roots at $\mathrm{pH} 9$ and 10 were still browner and did not become inoculated. It should be noted that plants at $\mathrm{pH} 9$ were a little taller than at $\mathrm{pH} 8$, but of a very poor color. In all other cultures at $\mathrm{pH} 8$ the plants were better than at $\mathrm{pH}$ 9. Table 3 gives dry weight of plants and number of nodules per plant.

The experiment just described was repeated using sand cultures according to general method already given. The same solution and reactions, were used as in the previous experiment. The extent of nodule formation was about the same as that in the solution cultures. The limits of nodule forma- 
tion were $\mathrm{pH} 4$ and 8 . There was less injury from an unfavorable reaction at $\mathrm{pH} 3,4,5,9$ and 10 than in the solution cultures at these reactions. This was perhaps due to a smaller amount of nutrient solution actually in contact with the plant roots in the sand cultures than in the solution cultures, and hence a lesser amount of acid or alkali, making it easier for the plants to change the actual reaction to a more favorable one. Plate 13 gives the comparative growth in sand cultures.

TABLE 3

Growth and inoculation of soybeans in Crone's mutrient solution at different reactions

\begin{tabular}{|c|c|c|c|}
\hline REACTION & $\left|\begin{array}{c}\text { DRY WEIGHT PER } \\
\text { PLANT }\end{array}\right|$ & $\begin{array}{l}\text { NODULES PER } \\
\text { PLANT }\end{array}$ & PLANT DEVELOPLENT \\
\hline$p H$ & $g m$. & & \\
\hline 3.30 & 0.24 & 0 & $\begin{array}{l}\text { Tops dead } \\
\text { Roots poor }\end{array}$ \\
\hline 3.97 & 0.40 & 0 & $\begin{array}{l}\text { Tops about dead } \\
\text { Roots poor }\end{array}$ \\
\hline 4.95 & 1.00 & 30 & $\begin{array}{l}\text { Tops fair } \\
\text { Roots dark and stubbed }\end{array}$ \\
\hline 6.50 & 1.42 & 77 & $\begin{array}{l}\text { Tops good } \\
\text { Roots good }\end{array}$ \\
\hline 7.40 & 1.42 & 68 & $\begin{array}{l}\text { Tops good } \\
\text { Roots good }\end{array}$ \\
\hline 8.20 & 1.15 & 21 & $\begin{array}{l}\text { Tops good } \\
\text { Roots slightly brown }\end{array}$ \\
\hline 8.70 & 1.00 & 3 & $\begin{array}{l}\text { Tops fair } \\
\text { Roots brown }\end{array}$ \\
\hline 9.60 & 0.60 & 0 & $\begin{array}{l}\text { Tops poor and yellow } \\
\text { Roots very brown }\end{array}$ \\
\hline
\end{tabular}

Comparative growth of soybeans, corn and cowpeas at different reactions

For a comparison with the soybean, corn and cowpeas were grown in both solution and sand cultures with Crone's solution in exactly the same manner as the previous experiment with soybeans, except that nitrates instead of chlorides were used in the solutions for corn.

Plates 11, 12 and 14 serve to indicate the general growth which the corn and cowpeas made. The corn in the alkaline range of the solution cultures did not make good growth and the leaves were yellow. This was perhaps due to the lack of iron in solution, which was caused by precipitation under the alkaline conditions. The corn in the sand cultures grew better than in solution cultures and none of it became yellow. Corn plants at $\mathrm{pH} 5$ in the sand cultures were inferior to the other plants at the beginning of the experiment and never grew as well as plants at $\mathrm{pH} 4$. The maximum growth of corn took place at $\mathrm{pH} 6$ and 7 in the sand cultures, and at $\mathrm{pH} 5$ and 6 in the solution cultures. Plate 15 indicates that corn can grow at a considerably more 
acid reaction than the cowpeas and soybeans. Apparently, as indicated in table 4 cowpeas have a wider range of inoculation than the soybeans. The corn was not grown in duplicate cultures and hence any conclusion with corn must be tentative.

TABLE 4

Growth and inoculation of cowpeas in sand cultures at different reaclions

\begin{tabular}{|c|c|c|}
\hline REACTION & NODULES PER PLANT & PLANT DEVELOPMENT \\
\hline$p H$ & & \\
\hline 3.3 & 0 & $\begin{array}{l}\text { Tops fair } \\
\text { Roots stubby and brown }\end{array}$ \\
\hline 3.97 & 20 & $\begin{array}{l}\text { Tops fair } \\
\text { Roots slightly dark }\end{array}$ \\
\hline 4.95 & 22 & Tops and roots good \\
\hline 6.5 & 32 & Good plants, roots, and tops \\
\hline 7.4 & 33 & Good plants, roots, and tops \\
\hline 8.2 & 26 & $\begin{array}{l}\text { Tops good } \\
\text { Roots slightly brown }\end{array}$ \\
\hline 8.7 & 19 & $\begin{array}{l}\text { Tops fair } \\
\text { Roots brown }\end{array}$ \\
\hline 9.6 & 14 & $\begin{array}{l}\text { Tops fair } \\
\text { Roots very brown }\end{array}$ \\
\hline
\end{tabular}

The infuence of the reaction of the culture medium on the reaction of the plant juices

The influence of the reaction of the culture medium on the reaction of the plant juices has been investigated by several workers $(17,38)$; and it was thought desirable to obtain additional information along this line. The reaction of the juices of the roots and leaves of some of the plants grown in the previous experiments was determined electrometrically by the method de-

TABLE 5

The reaction of the juices of plants grown in media of different reactions

\begin{tabular}{|c|c|c|c|c|c|c|}
\hline \multirow{2}{*}{$\begin{array}{l}\text { REACTION OF } \\
\text { MEDIA }\end{array}$} & \multicolumn{2}{|c|}{ SOYBEANS } & \multicolumn{2}{|c|}{ COWPEAS } & \multicolumn{2}{|c|}{ CORN } \\
\hline & Leaves & Roots & Leaves & Roots & Leaves & Roots \\
\hline$p H$ & $p H$ & $p H$ & $p B$ & $p H$ & $p H$ & $p H$ \\
\hline 3.30 & 5.60 & 4.68 & 5.33 & 4.89 & 5.19 & 4.99 \\
\hline 3.97 & 5.90 & 5.09 & 5.37 & 5.37 & 5.20 & 5.46 \\
\hline 4.95 & 6.08 & 5.29 & 5.38 & 5.77 & 5.18 & 5.55 \\
\hline 6.50 & 6.11 & 5.61 & 5.41 & 5.95 & 5.21 & 5.71 \\
\hline 7.40 & 6.12 & 5.75 & 5.47 & 6.07 & 5.20 & 5.90 \\
\hline 8.20 & 6.11 & 5.85 & 5.50 & 6.14 & 5.19 & 5.90 \\
\hline 8.70 & 6.14 & 6.29 & 5.53 & 6.25 & 5.21 & 6.10 \\
\hline 9.65 & 6.16 & 7.12 & 5.46 & 6.58 & 5.11 & 6.32 \\
\hline
\end{tabular}


scribed by Clevenger (8) and Haas (17). The results are recorded in table 5 . In general, the reactions of the plant juices as had previously been suggested (38) became more acid as the culture medium rose in acidity. The corn tops, however, showed no appreciable change. The reactions of the root juices were more nearly like those of the culture medium than were those of the leaves.

\section{DISCUSSION}

In making a comparison of the data presented, it should be clearly understood that $\mathrm{pH} 3$ signifies an acidity ten times greater than $\mathrm{pH} 4$, and $\mathrm{pH} 4$ ten times greater than $\mathrm{pH} 5$, etc. Hence, a small change in $\mathrm{pH}$ means a great difference in hydrogen-ion concentration. It will be noted from the data that the most favorable reaction for plant growth and nodule formation with soybean was from $\mathrm{pH} 6$ to 7 , which is a condition of slight acidity. This fact

TABLE 6

Change in reaction of Crone's mutrient solution in contact with soybean roots for 24 hours, as determined by the hydrogen electrode

\begin{tabular}{c|c|c}
\hline CULTURE NUMBER & INITIAL REACTION & FINAL REACTION \\
\cline { 2 - 3 } 3 & $p$ pH & $p H$ \\
4 & 3.30 & 3.30 \\
5 & 3.95 & 4.00 \\
0 & 4.80 & 5.10 \\
7 & 6.90 & 6.10 \\
8 & 7.80 & 7.00 \\
9 & 8.70 & 7.90 \\
10 & 9.50 & 8.80 \\
& 9.70 & 9.40 \\
\hline
\end{tabular}

was indicated more clearly in the solution cultures than in the sand culture. The reactions at which maximum grow th took place agrees with those reported by Hoagland (23) and Salter and McIlvane (34). Corn grew at a much stronger acidity than soybeans. This conforms with field observations.

The unsatisfactory results obtained in solution cultures with the modified form of Shive's nutrient solution are not readily explained since the plants grew well and became inoculated fairly well in the sand cultures. It was thought that possibly the salts used contained toxic substances which the sand adsorbed and thus prevented their toxic effect on the plants. In order to test this possibility some of the solution was thoroughly shaken with activated charcoal before being used. This appreciably lessened the injurious effects on the roots, but still no nodules appeared. Wilson (39) failed to obtain any nodules with soybeans in solution cultures using Pfeffer's nutrient solution even after varying the amount of nitrates. This same thing was found to be true with Shive's nutrient solution in the present investigation. 
German and Didlake (13) reported inoculation of soybeans in solution cultures, using a nitrogen free commercial fertilizer for the nutrient salts. The writer believes that the unsatisfactory results obtained with Shive's nutrient solution in solution cultures were possibly due to toxic impurities in the salts used.

Crone's nutrient solution was not entirely satisfactory in the alkaline range because of the difficulty of maintaining a constant reaction when in contact with growing plants. This was even true to some extent after the addition of sodium carbonate as is indicated in table 6 . The acid range was much more constant than the alkaline range, although it changed some. This same difficulty exists, of course, to some extent with all nutrient solutions, especially if the plants grow well in them.

The carbon dioxide excreted by the plant roots and that absorbed from the atmosphere were no doubt large factors in changing the reaction in the alkaline range.

It was found in the present investigation that when sodium glycero phosphate was added to Crone's solution the reaction remained almost constant for a daily period, but no nodules were formed in solution cultures. The addition of dibasic potassium phosphate to the alkaline range of Crone's solution was also found to hold the reaction of the solution fairly constant for daily periods, but nodule formation was again poor. In general, the reaction of a solution which was fairly favorable to plant growth so that considerable growth took place, would not remain constant very long in contact with the growing plants, unless the initial reaction of the solution was exactly the one most favorable for the plants. The change in reaction of the solution due to growing plants was always in the direction of a more favorable reaction. Salter and McIlvane's data (34) indicate that the reaction of their nutrient solution in contact with growing plants remained nearly constant during four-day periods. This was possibly due to the slow rate of growth of their plants.

The data show that pure cultures of soybean bacteria are able to grow at an acid reaction almost as great as that of the host plant. These results are not exactly in line with those of Bewley and Hutchinson (2) who reported that definitely acid soils would finally kill the nodule bacteria of lupines, red clover, and broad bean. However, they did not state the exact degree of acidity of the soil used and hence it is possible that they worked with very strongly acid soils. It will be seen from tables 2 and 3 that the best inoculation took place at a slightly acid to neutral reaction, although some inoculation took place at a reaction of $\mathrm{pH} 5$ and even $\mathrm{pH} 4$. The information secured thus far does not indicate that the critical hydrogen-ion concentration of pure cultures of the soybean bacteria is different from what it is in the soil.

The results show distinctly that the reaction of the media in which the soybeans are grown has a direct influence on growth and inoculation. The reactions which produced injury and poor inoculation were within the range of reactions of actual soil solutions and suspensions as reported by Gillespie 
(15) Sharp and Hoagland (35), Plummer (32) Truog (37) and others. Different plants vary considerably in their ability to grow at reactions of $\mathrm{pH} 4,5$, and 6. Thus it will be seen that a proper adjustment of the reaction of the soil for different plants is of prime importance for the best growth and inoculation.

The reaction of the media in which the plants are grown often has a direct influence on the reaction of the plant juices. Further studies on the influence of reaction on legumes and legume bacteria are in progress.

\section{SUMMARY}

A study was made of the influence of acidity and alkalinity on growth and inoculation of soybeans in solution and sand cultures. The plants were grown in 500- and 600-cc. percolators. A modified form of Shive's nutrient solution was used at first, but with unsatisfactory results in solution cultures. Three other nutrient solutions were tested for influence on inoculation in solution cultures. Of these, Crone's nutrient solution proved to be the most satisfactory, and was selected with slight modification for the principal work reported herein. The reactions of the solutions were adjusted by adding varied amounts of acid or alkali as the case required. The reactions were kept as constant as possible by renewing the solutions daily. The old solutions were removed from the sand with suction before the new solutions were added. The cultures were allowed to grow from 25 to 35 days after inoculation. A few cultures of corn and cowpeas were grown under similar conditions to that of the soybean for comparison. Twenty-one different strains of soybean bacteria were grown on pure cultures of different reactions in order to compare the critical hydrogen-ion concentration of the soybean bacteria with that of the host plant.

1. Shive's nutrient solution was favorable for growth and inoculation of soybeans in sand cultures, but not in solution cultures. It seems possible that there were toxic impurities in the nutrient salts used which were adsorbed by the sand.

2. Crone's nutrient solution was favorable for growth and inoculation in both solution and sand cultures. The alkaline range of this solution has a very poor buffer action, which is improved markedly by the addition of $\frac{3}{4} \mathrm{gm}$. of sodium carbonate per liter.

3. The reaction of the nutrient solution in contact with growing plants does not remain constant very long, unless the initial reaction of the solution is the most favorable one for the plants. The rate of change in reaction is greater in the alkaline range than in the acid range. Plants growing rapidly apparently influence this rate of change more than slow growing plants.

4. The most favorable reaction for growth and inoculation of soybeans was $\mathrm{pH}$ 6.5. The limits for which inoculation took place were about $\mathrm{pH} 4.6$ and 8. The limits for growth of soybeans were about $\mathrm{pH} 3.9$ and 9.6. Reactions $\mathrm{pH} 4.95$ and 8.2 are injurious to the growth of soybeans, but do not entirely prevent inoculation. 
5. The hydrogen-ion concentrations which were markedly injurious to plant growth and inoculation in this investigation were not any greater and in some cases considerably less than the hydrogen-ion concentration of very acid soil solutions and suspensions as reported by recent investigators.

6. The critical hydrogen-ion concentration for nodule formation of soybeans was slightly less than that for plant growth. The different strains of soybean bacteria showed small differences in regard to critical hydrogen-ion concentration.

7. Corn grew at a greater acidity and alkalinity than the soybean or cowpea. The cowpea apparently has a greater range of reaction at which nodules are formed than the soybean.

8. The reaction of plant juices varied with the degree of acidity or alkalinity at which the plants were grown, except in the case of the juice of the corn leaves which showed little change. The juices of the roots followed the reaction of the media more closely than did the juices of the leaves.

\section{REFERENCES}

(1) Aвbotr, J. B., Conner, S. D. And Smalley, H. R. 1913 Soil acidity, nitrification and the toxicity of soluble salts of aluminum. Ind. Agr. Exp. Sta. Bul. 170.

(2) Bewlex, W. F., AND Hutchinson, H. B. 1920 On the change through which the nodule organism (PS. Radicicola) passes under cultural conditions. In Jour. Agr. Sci., v. 10, part 2, p. 144-162.

(3) Breazeale., J. F., ANd LeClerc, J. A. 1912 The growth of wheat seedlings as affected by acid or alkali conditions. U. S. Dept. Agr. Bur. Chem. Bul. 149.

(4) Caumeron, F. K., and Breazeale, J. F. 1904 The toxic action of acids and salts on seedlings. In Jour. Phys. Chem., v. 8, no. 1, p. 1-13.

(5) Clark, W. M., AND LuBs, H. A. 1917 The colorimetric determination of hydrogenion concentration and its application to bacteriology. In Jour. Bact., v. 2, no. 1, p. 109-191, v. 3, p. 217-242.

(6) ConNer, S. D. 1921 Liming and its relation to injurious inorganic compounds in the soil. In Jour. Amer. Soc. Agron., v. 13, no. 3, p. 115-124.

(7) Crone, G. von DER 1902 Ergebnisse von Untersuchungen über die Wirkung der Phosphorsäure auf die höhere Pflanze. In Sitzber. Gesell. Natur. u. Heilk. Bonn, 1903 , p. $167-173$

(8) Clevenger, C. B. 1919 Hydrogen-ion concentration of plant juices. In Soil Sci., v, 8, no. 3, p. 217-242.

(9) Duggar, B. M. 1920 Hydrogen-ion concentration and the composition of nutrient solutions in relation to the growth of seed plants. In Ann. Mo. Bot. Gar., v. 7, no. 1, p. $1-49$.

(10) Dachnowshr, A. 1914 The effect of acid and alkaline solutions upon the water relation and metabolism of plants. In Amer. Jour. Bot., v. 1, p. 412-443.

(11) FRED, E. B., AND LOOMIS, N. E. 1917 Influence of hydrogen-ion concentration on the development of alfalfa bacteria. In Jour. Bact., v. 2, p. 629-633.

(12) Fred, E. B., AND Davenport, AunRey 1918 Influence of reaction on nitrogen assimilating bacteria. In Jour. Agr. Res., v. 14, no. 8, p. 317-336.

(13) Garman, H., and Didlake, Mary 1914 Six different species of nodule bacteria. Ky. Agr. Exp. Sta. Bul., 184.

(14) Gruzit, O. M. 1917 The effects of some acids and alkalies on soil bacteria in solution. In Soil Sci., v. 3, p. 289-295. 
(15) GrLLespIE, L. J. 1916 The reaction of the soil and measurement of hydrogen-ion concentration. In Jour. Wash. Acad. Sci., v. 6, no. 1, p. 7-16.

(16) Gillespie, L. J. 1920 Colorimetric determination of hydrogen-ion concentration without buffer mixtures, with special reference to soils. In Soil Sci., v. 9, no. 2, p. 115-136.

(17) HaAs, A. R. C. 1920 Studies on the reactions of plant juices. In Soil Sci., v. 9, no. 5, p. 341-368.

(18) Hartwelt, B. L., And Pember, F. R. 1907 The relation between the effect of liming and different nutrient solutions containing different amounts of acids, upon the growth of certain cereals. In R. I. Agr. Exp. Sta. 20th Ann. Rpt., p. 358-380.

(19) Hartweli, B. L., AND PEMBER, F. R. 1918 The presence of aluminum as a reason for the difference in effect of so-called acid soils on barley and rye. In Soil Sci., v. 6, p. $259-277$.

(20) Heald, F. D. 1896 On the toxic effects of dilute solutions of acid and salts on plants. In Bot. Gaz., v. 22, no. 2, p. 125-153.

(21) HiltneR, L. 1915 The sensitiveness of different lupines and other plants to lime. Prakt. Bl. Pflanzinbau u. Schutz, n. s., 13, no. 5, p. 53-59; abs. Exp. Sta. Rec., v. 35, p. 430.

(22) Hrxon, R. M. 1920 The effects of reaction of a nutrient solution on germination and first stages of plant growth. In Meddel. K. Vet. Akad. Nobel-Institute, v. 4 , nо. 9 , p. $1-28$

(23) Hoagland, D. R. 1918 Effect of hydrogen- and hydroxyl-ion concentration on growth of barley seedlings. In Soil Sci., v. 3, no. 6, p. 559-560.

(24) Hopkins, C. G., ANd Petrit, J. H. 1910 Soil Fertility Laboratory Manual, p. 22 Ginn \& Co., New York.

(25) Jofre, J. S. 1920 The effects of soil reaction on the growth of alfalfa. In Soil Sci., v. 10 , no. 4 , p. $301-307$.

(26) KAHLENBERG, L., AND TRUE, R. O. 1896 On the toxic action of dissolved salts and their electrolytic dissociation. In Bot. Gaz., v. 22, no. 2, p. 81-124.

(27) KAPPEN, H. 1918 Untersuchangen und Wurzelsäften. In Landw. Vers. Stat., Bd. 91, p. 40.

(28) Kappen, H. 1920 Über die Aziditätsforms des Bodens und ihre Phlanzenphysiologische Bedeutung. In Landw. Vers. Stat., v. 96, p. 306-307.

(29) Loew, F. A. 1903 Toxic effects of hydrogen- and hydroxyl-ions on seedlings of Indian corn. In Science, n. s., v. 18, no. 453, p. 304-308.

(30) Mrrasol, J. J. 1920 Aluminum as a factor in soil acidity. In Soil Sci., v. 10, no. 3, p. 153-219.

(31) McCall, A. G. 1916 Physiological balance of nutrient solution for plants in sand cultures. In Soil Sci., v. 2, p. 207-254.

(32) Plunmer, J. K. 1918 Studies on the soil reaction as indicated by the hydrogen electrode. In Jour. Agr. Res., v. 12, p. 19-31.

(33) SALter, R. C. 1916 The behavior of legume bacteria on acid and alkali media. In Proc. Iowa Acad. Sci., v. 23, p. 309-313.

(34) Salter, R. M., and McIlvane, F. C. 1920 The effect of reaction of solution on germination of seed and growth of seedlings. In Jour. Agr. Res., v. 19, no. 2, p. 73-96.

(35) Sharp, L. T., .and Hoagland, D. R. 1916 Acidity and absorption of the soil as measured by the hydrogen electrode. In Jour. Agr. Res., v. 7, no. 3, p. 123-145.

(36) SHIve, J. W. 1918 A study of physiological balance in nutrient media. In Physiol. Res., v. 1, no. 7, p. 327-397.

(37) Truog, E. 1918 Soil acidity: Its relation to the growth of plants. In Soil Sci. v. 5 , no. 3 , p. 169-195. 
(38) Truog, E., and Meacham, M. R. 1919 Soil acidity: Its relation to the acidity of plant juices. In Soil Sci., v. 7, no. 6, p. 469-475.

(39) Wrison, J. K. 1917 Physiological studies of the Bacillus Radicicola of the soybean (Soja Max Piper) and of the factors influencing nodule production. N. Y. (Cornell) U. Agr. Exp. Sta. Bul. 285. 


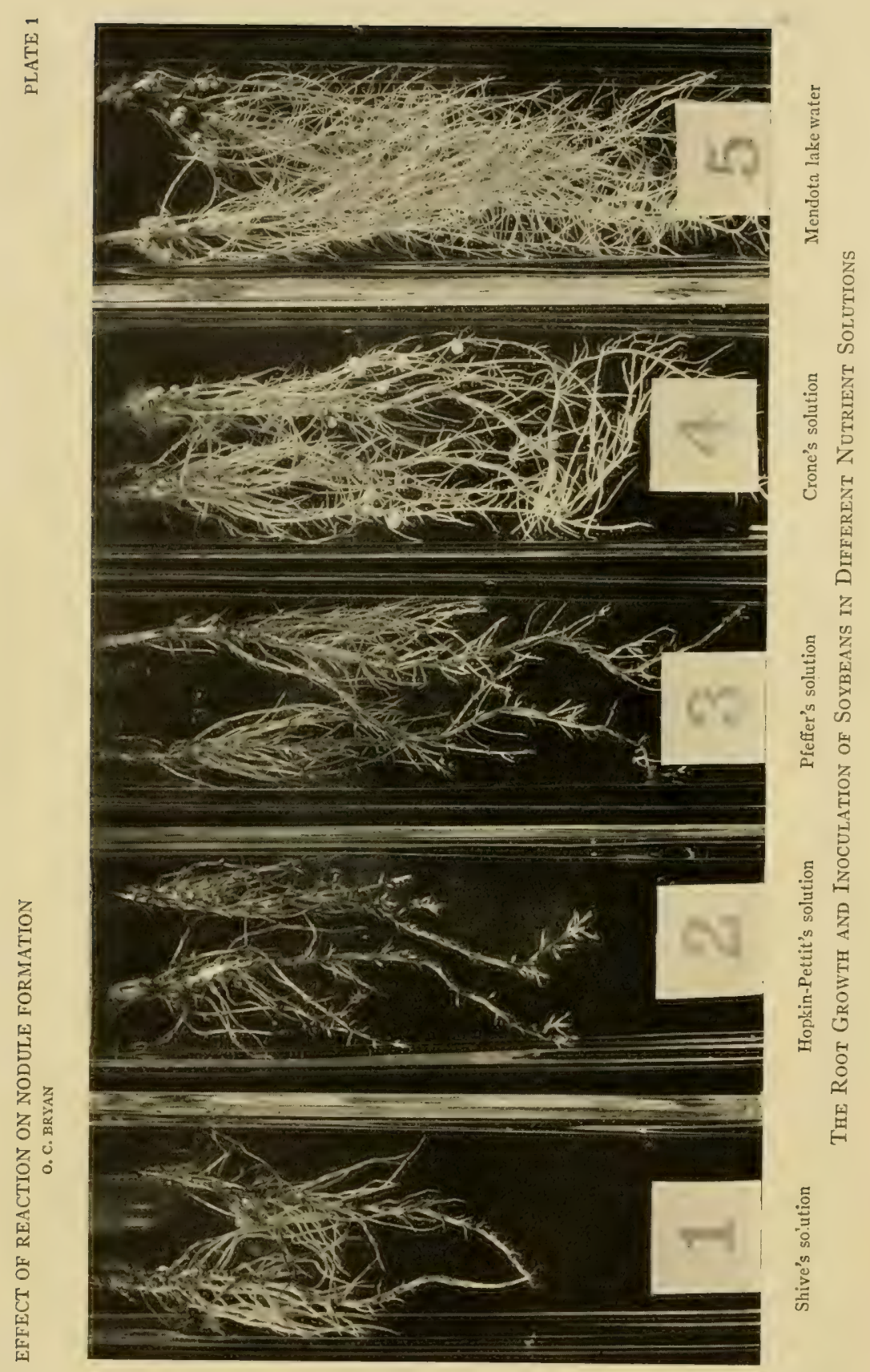


紫

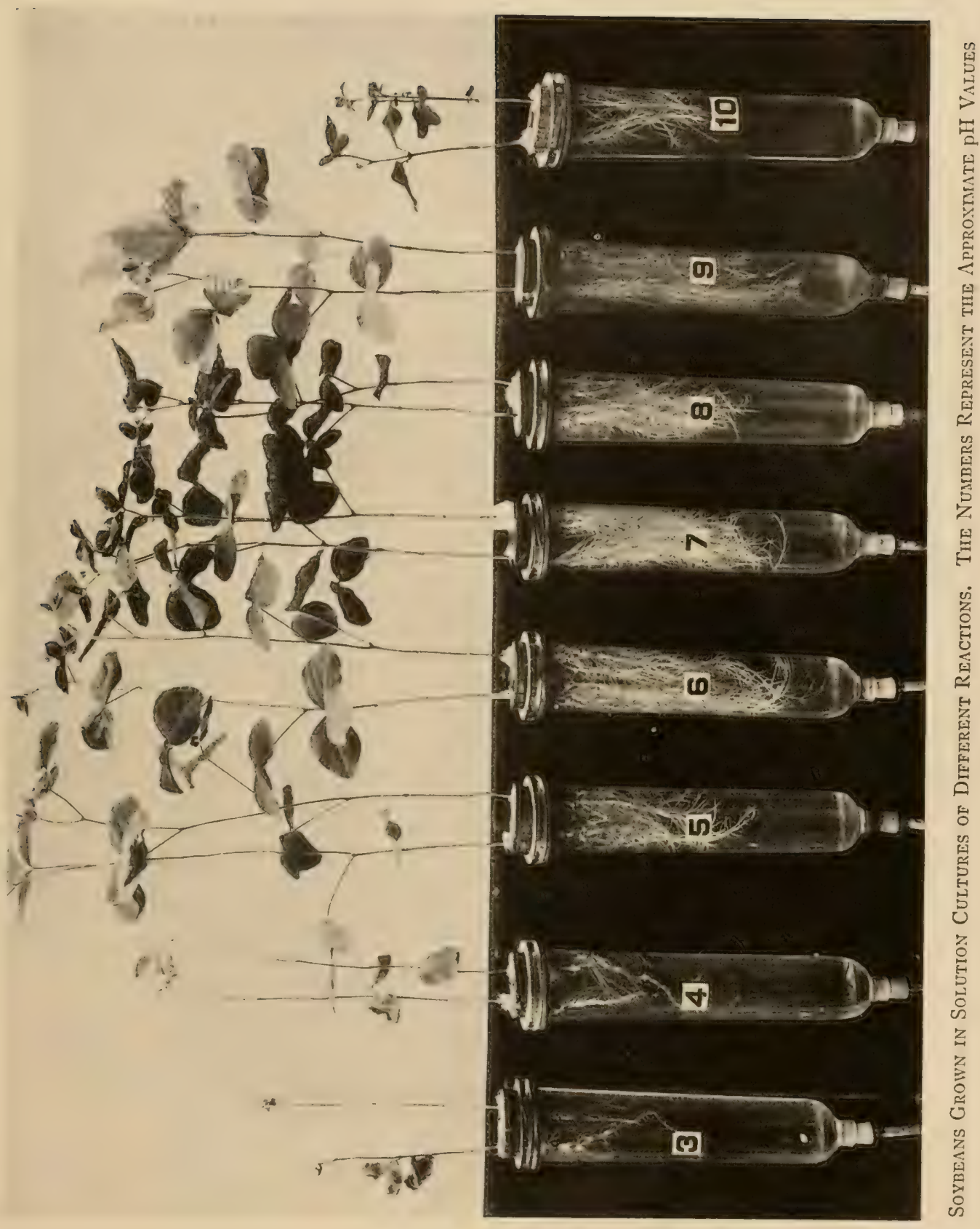




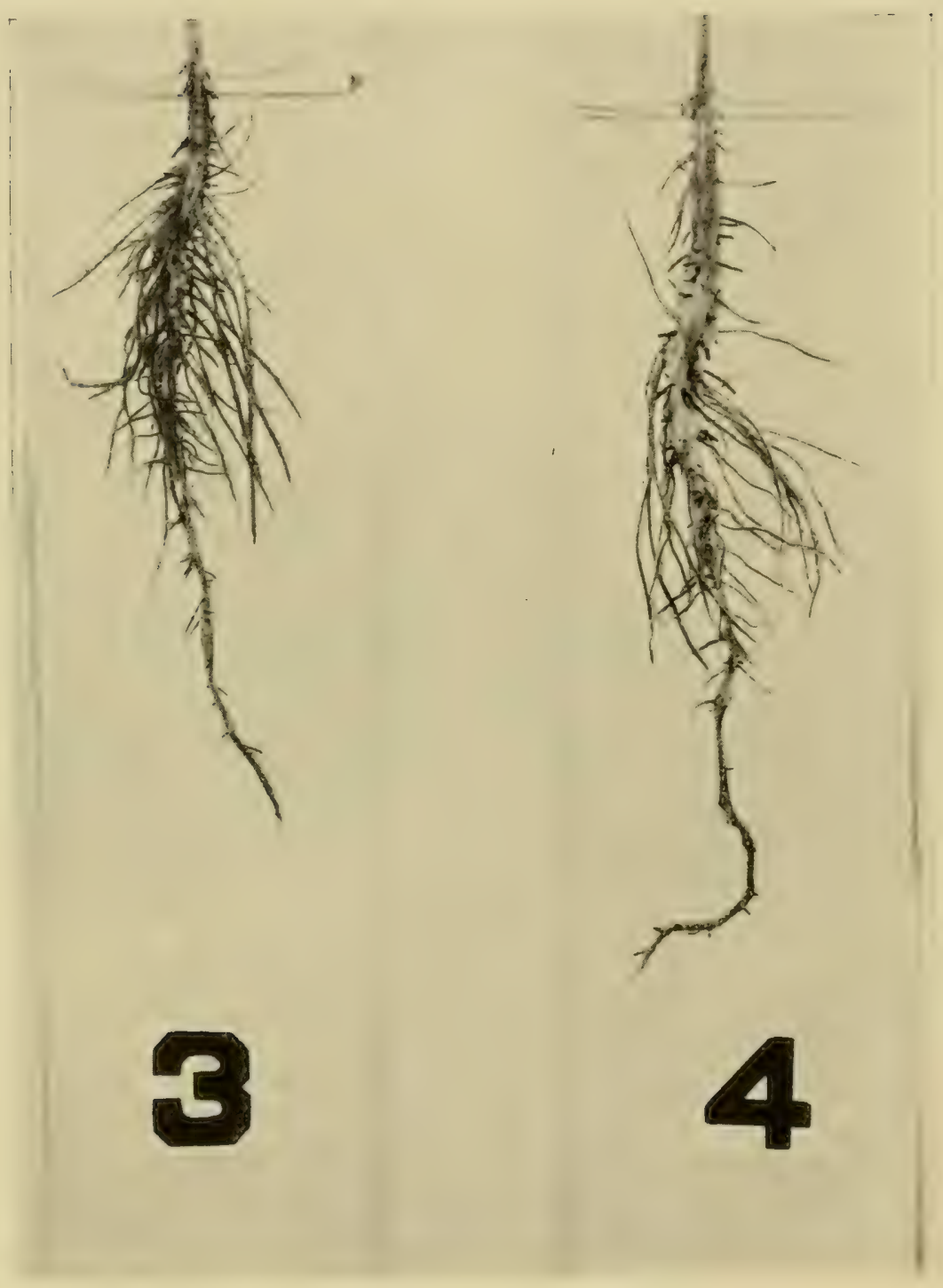

Soybean Roots Grown in Solution Cultures with pH Values of Approximately 3 AND 4 


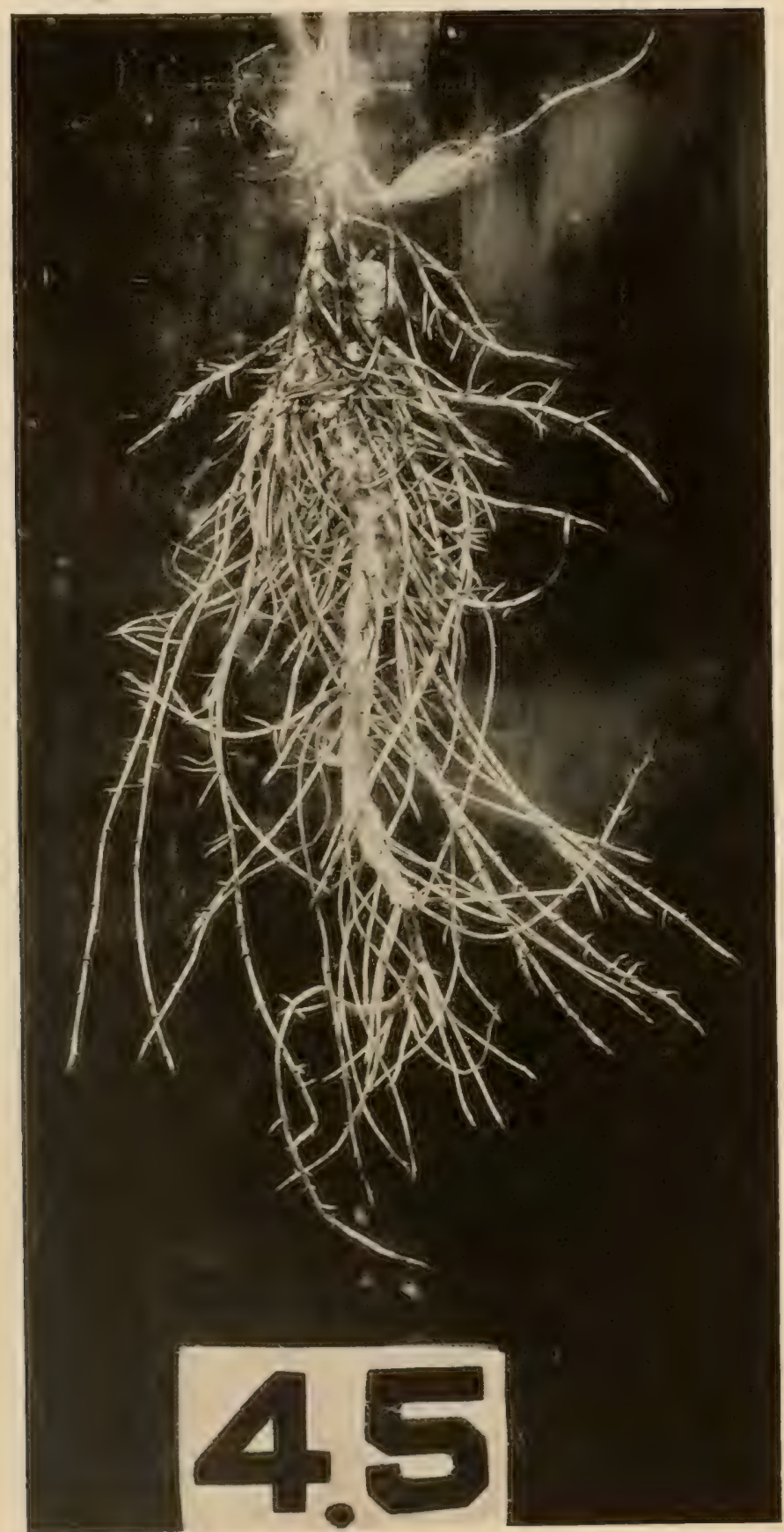

Soybean Roots Grown in Solution Culture with pH Value of Approximately 4.5 


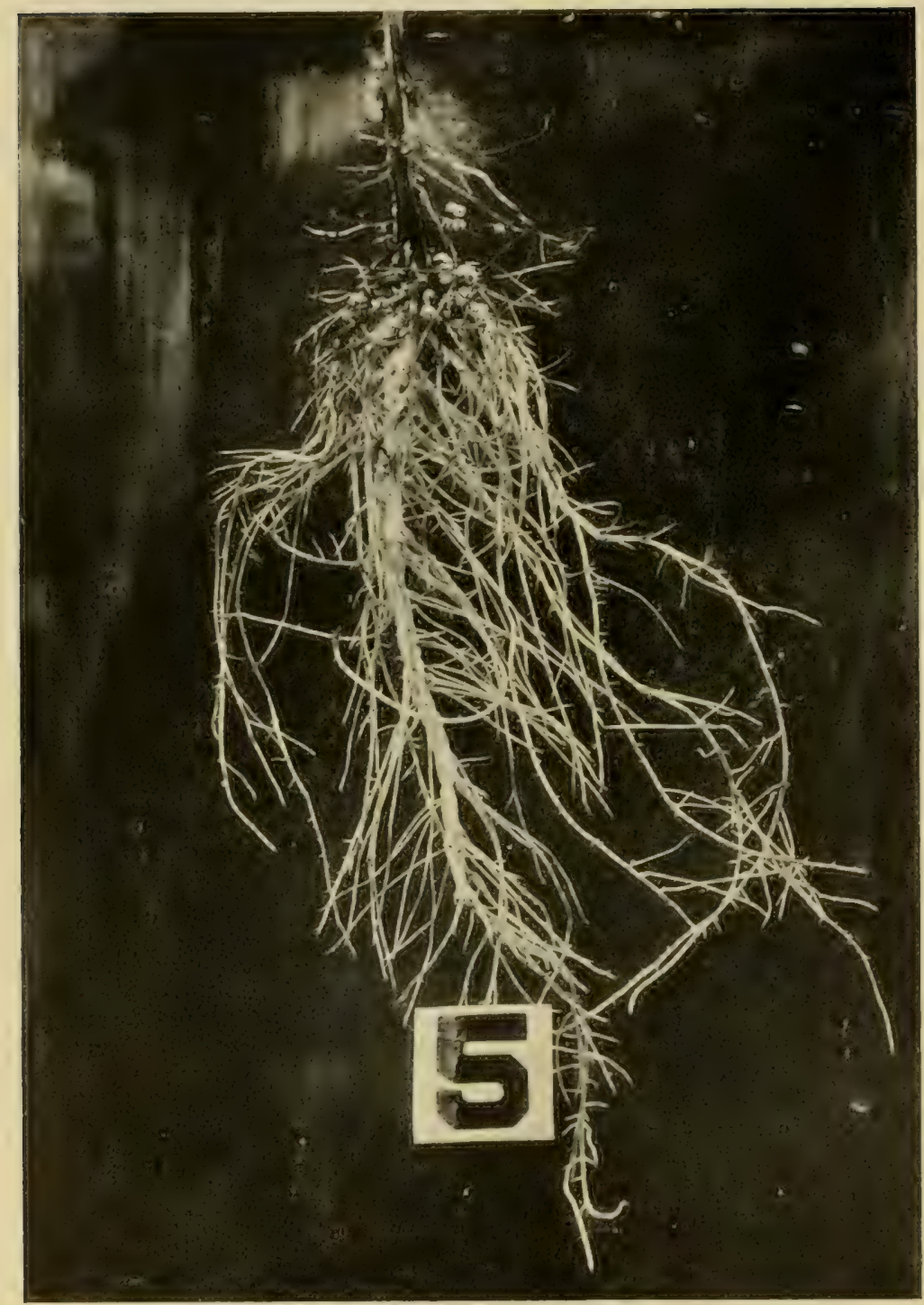

Soybean Roots Grown in Solution Culture with pH Value of Approximately 5 


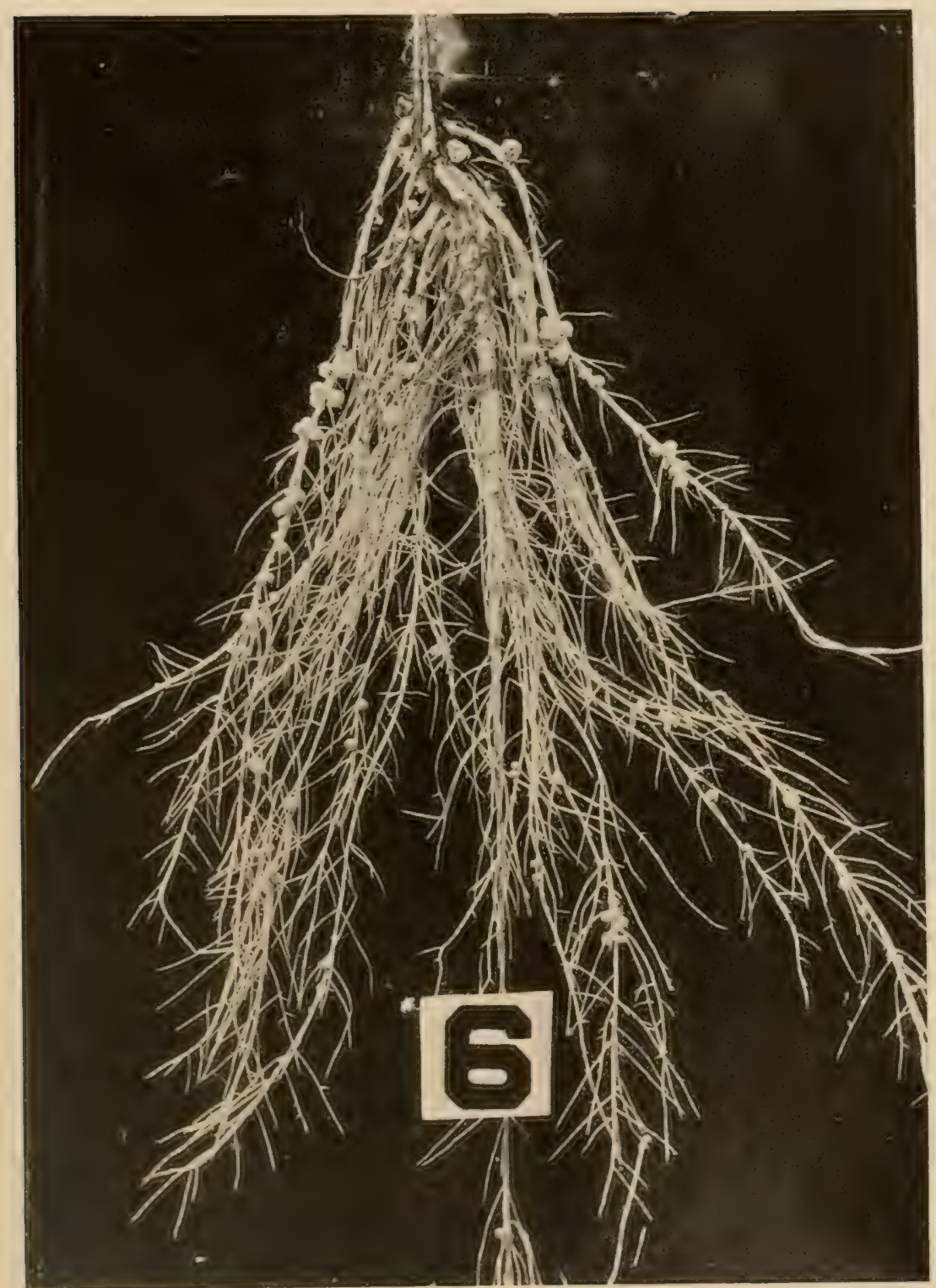

Soybean Roots Grown in Solution Culture with pH Value of Approximately 6 


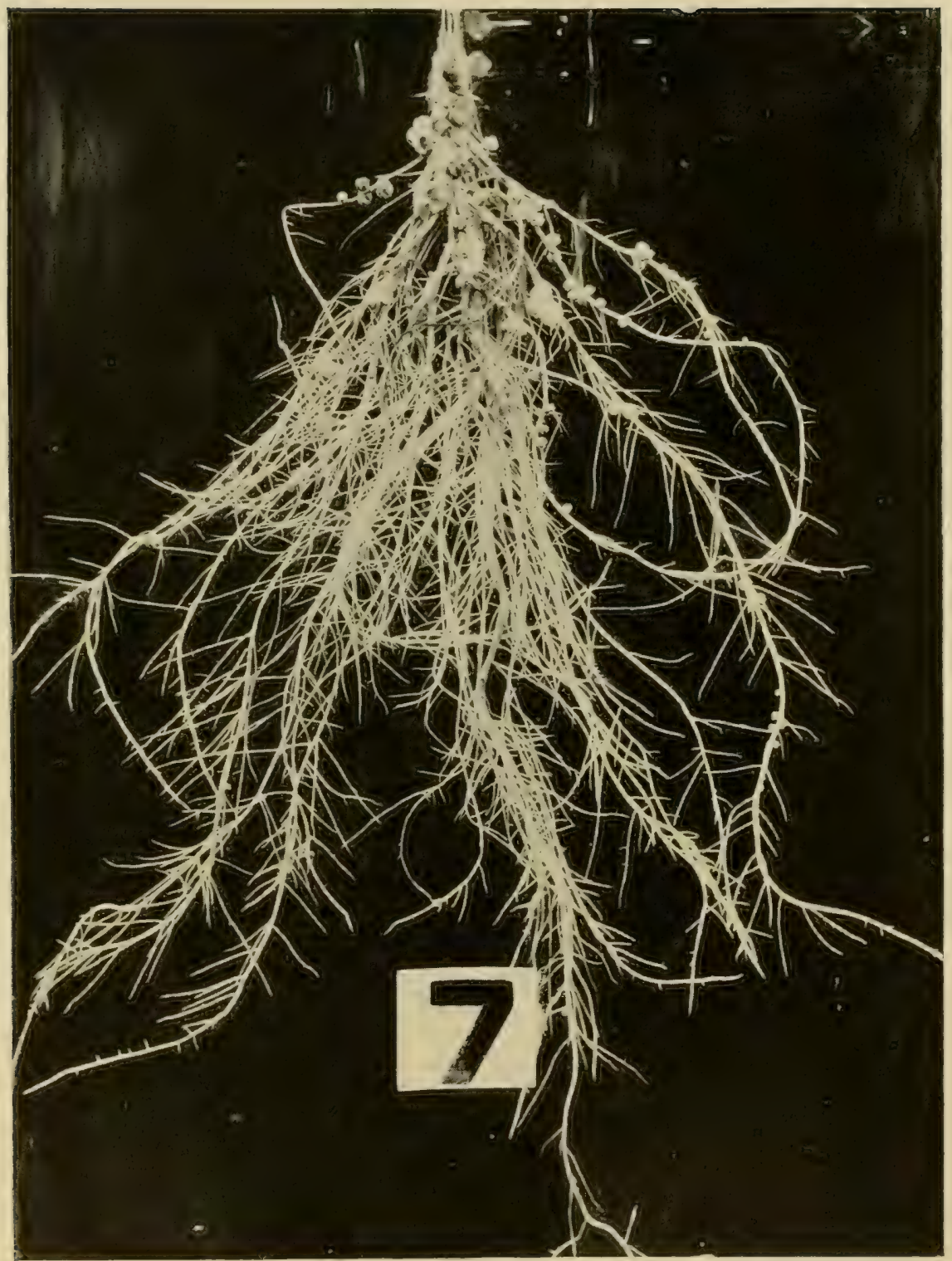

Soybean Roots Grown in Solution Culture with pH Value of Approximately 7 


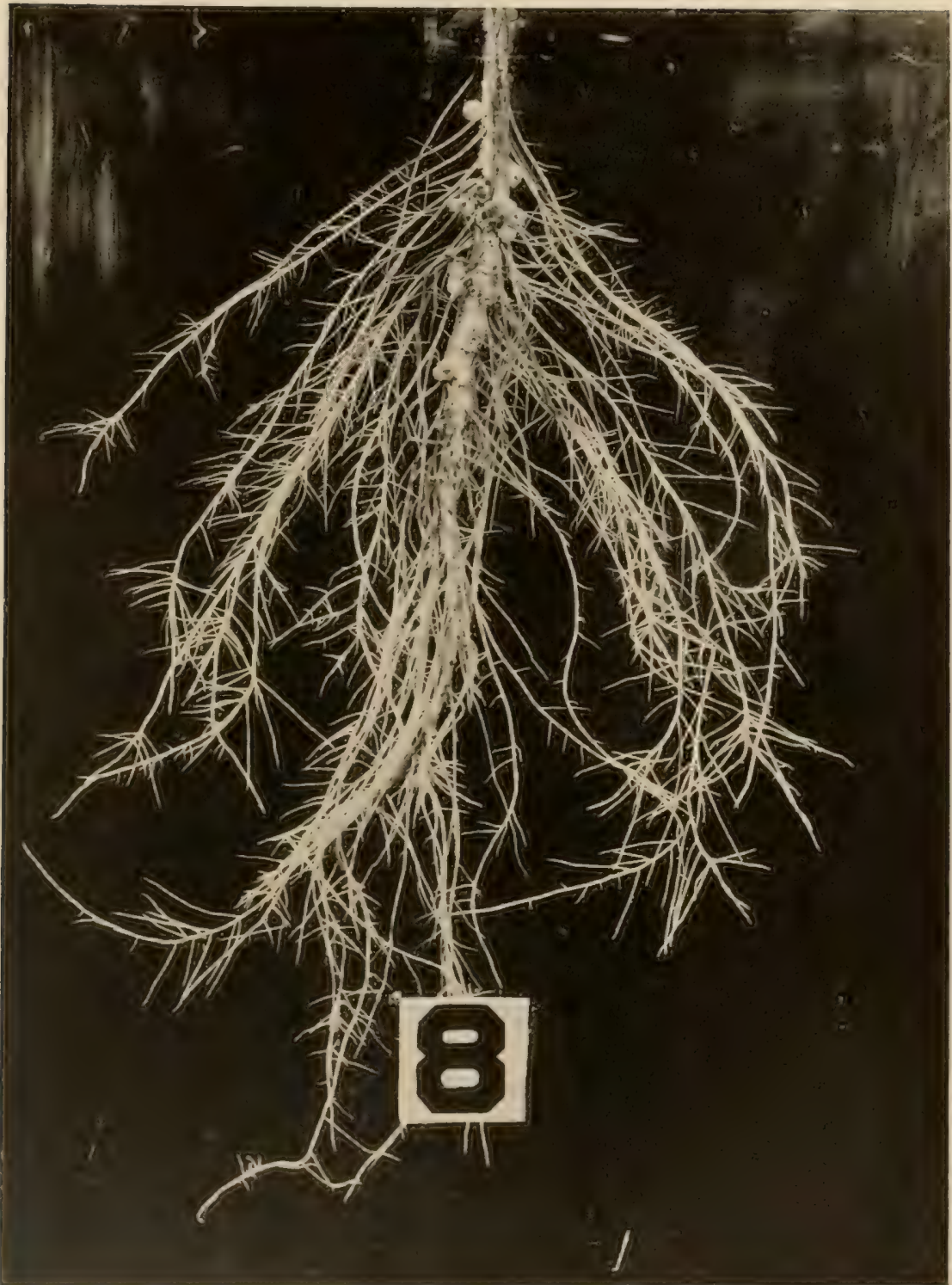

Soybean Roots Grown in Solution Culture with pH Value of Approxtmately 8 


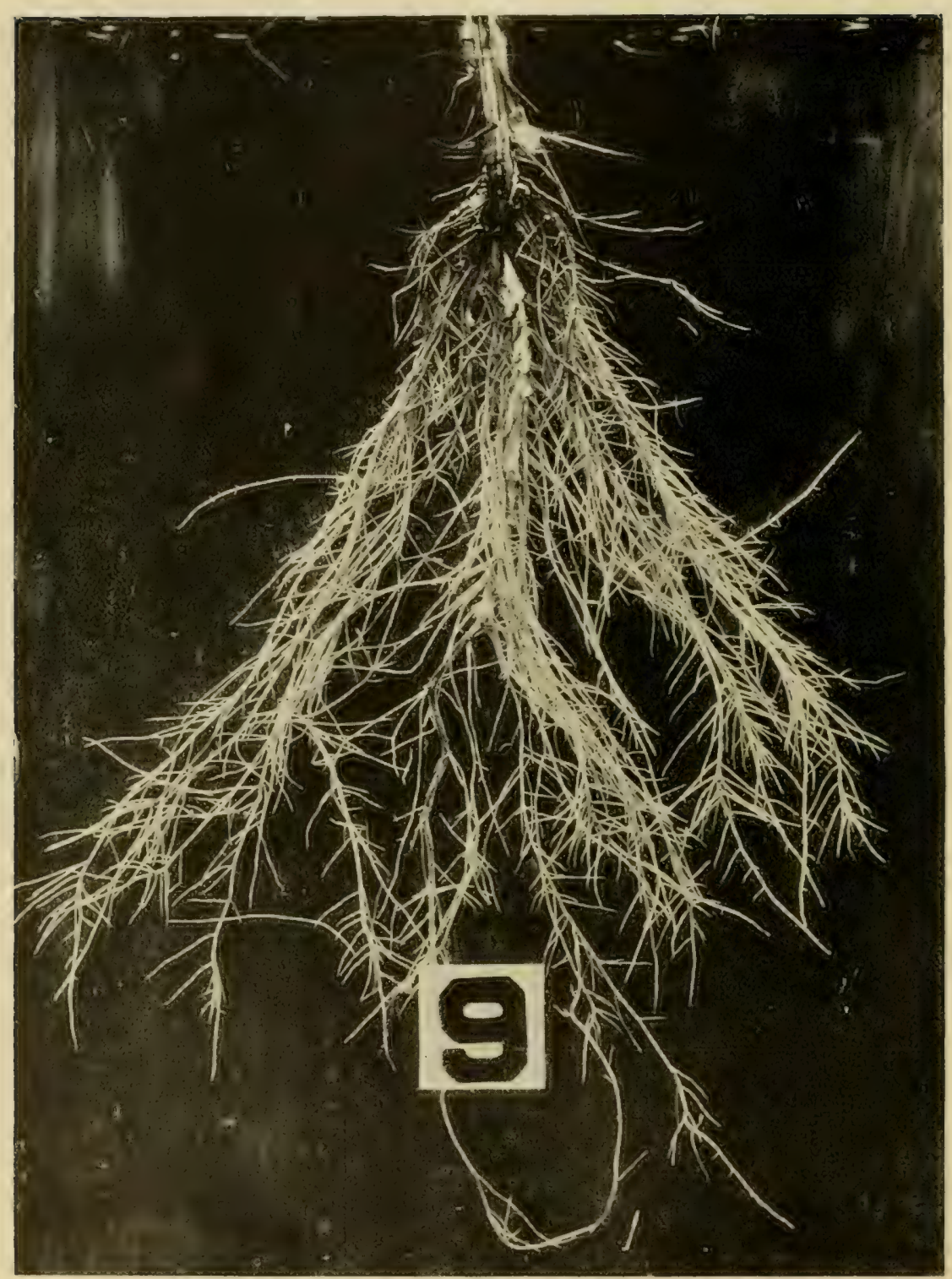

Soybean Roots Grown in Solution Culture with pH Value of Approximately 9 


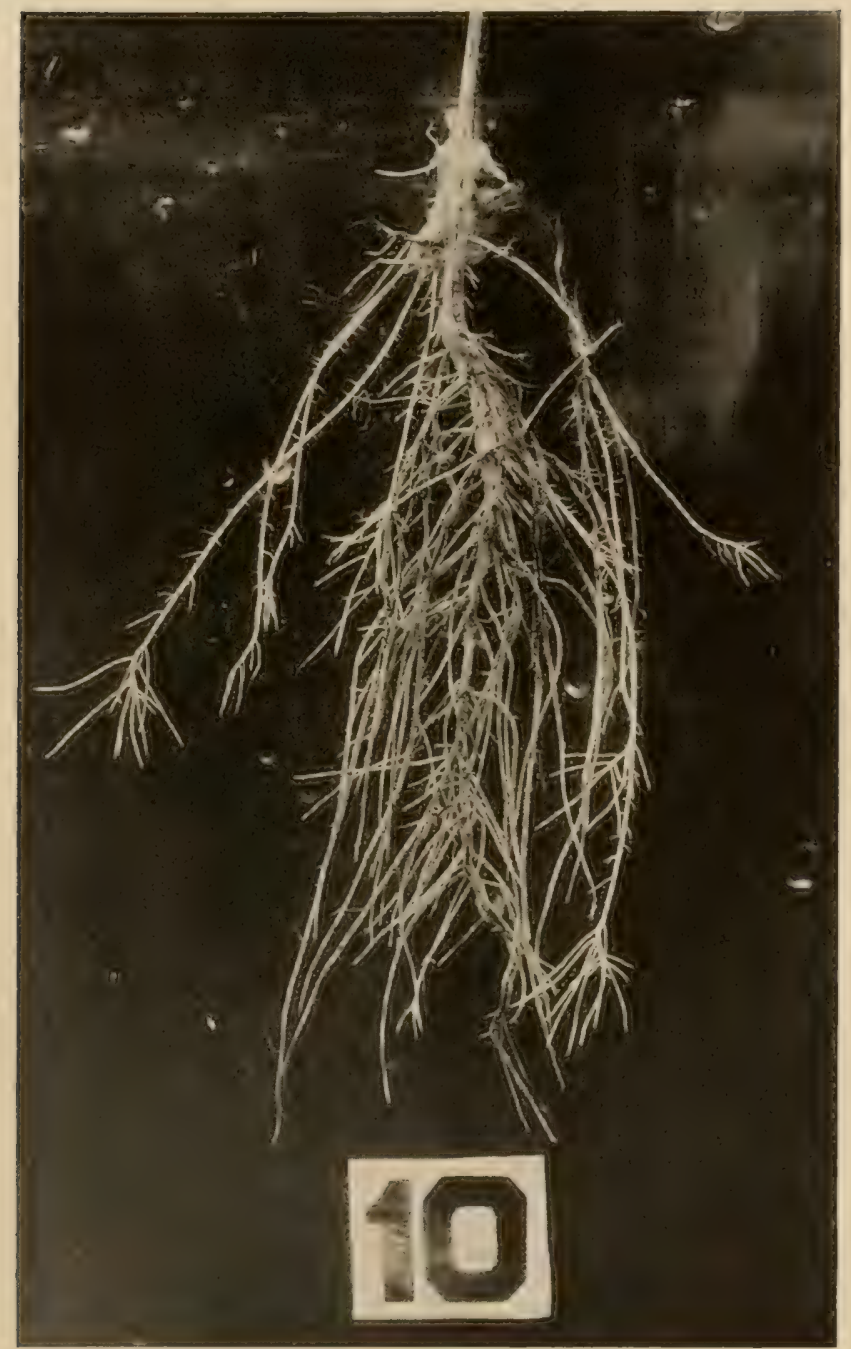

Soybean Roots Grown in Solution Culture with pH Value of Approxmitately 10 


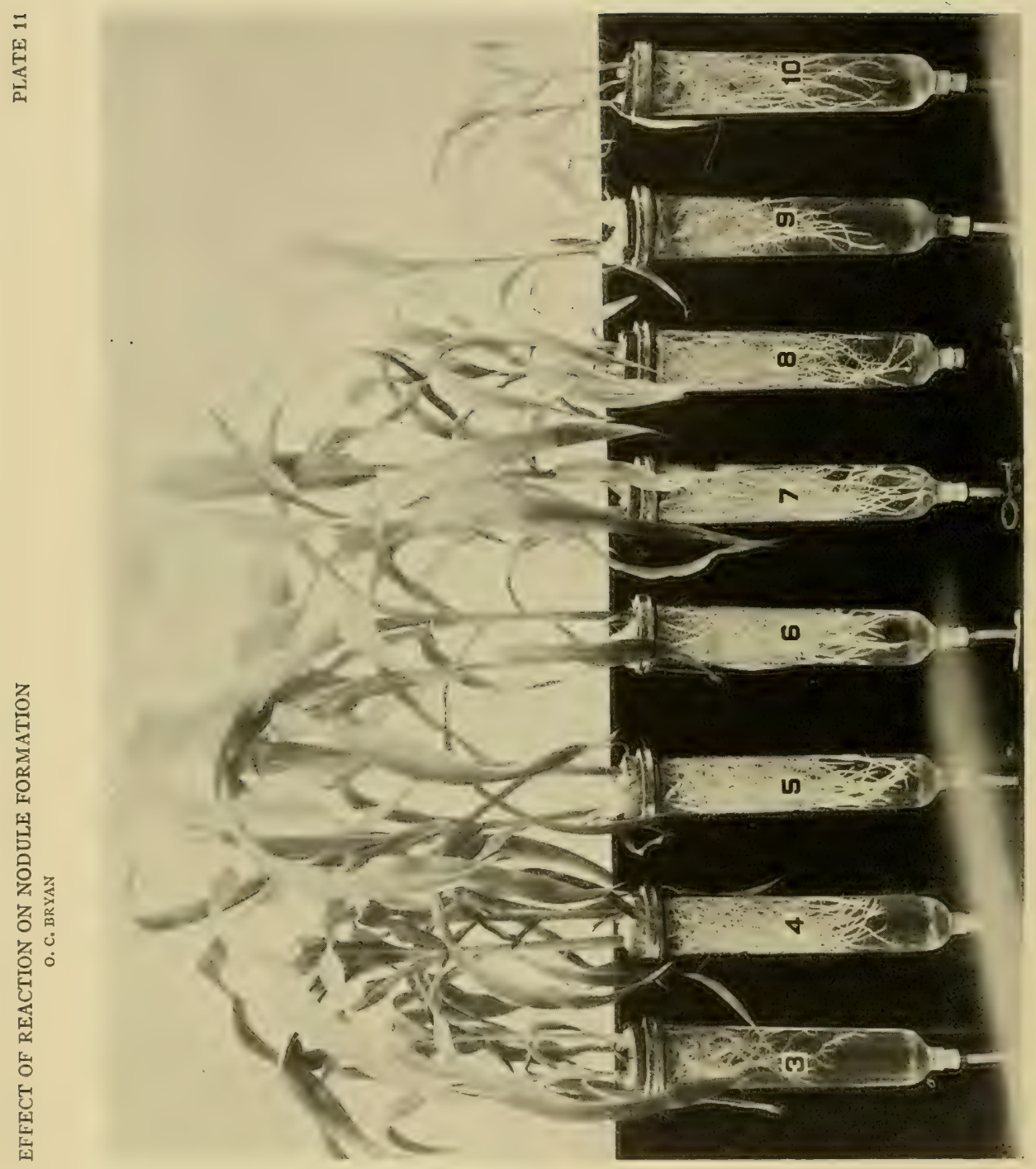

垔 


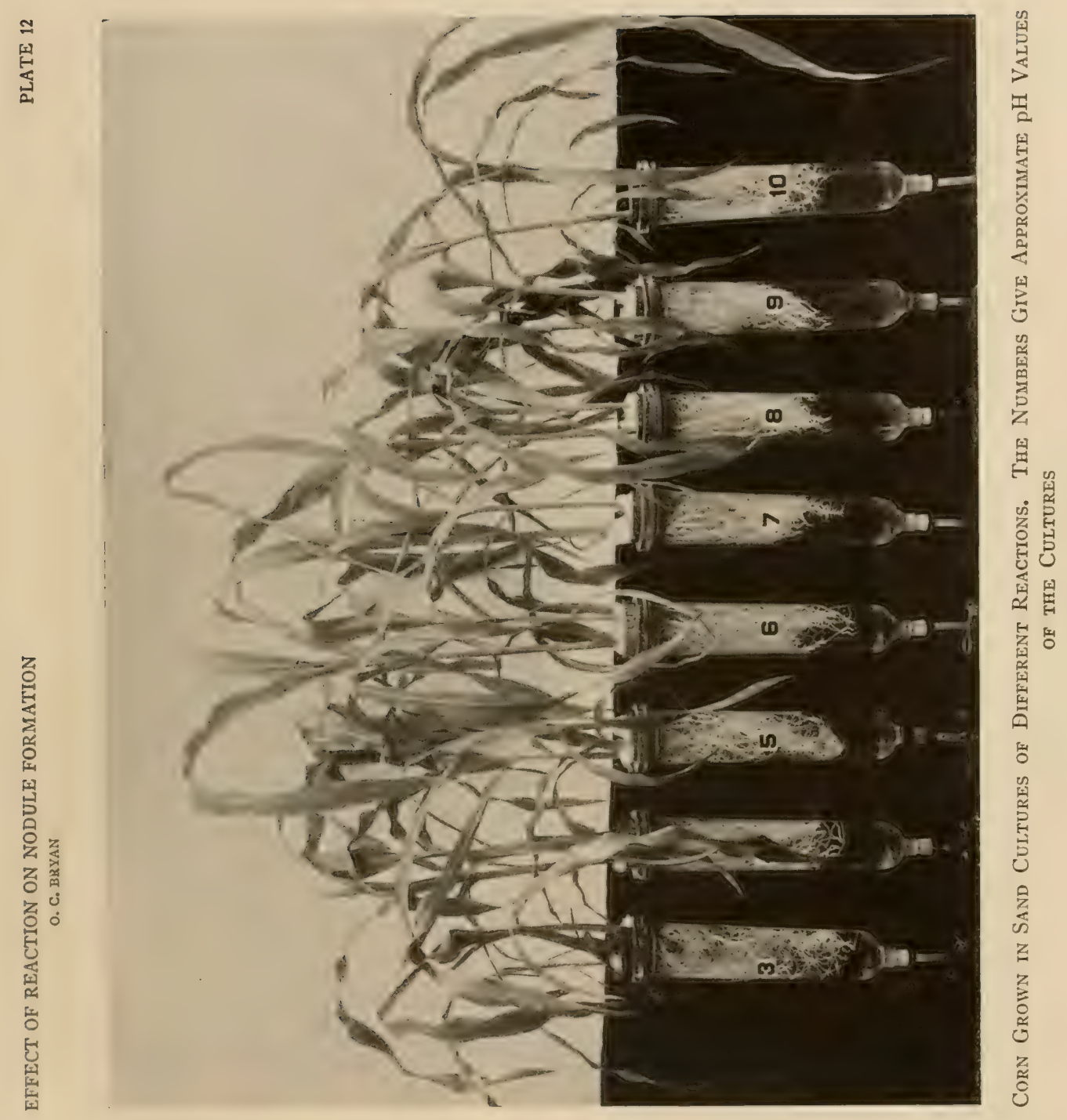




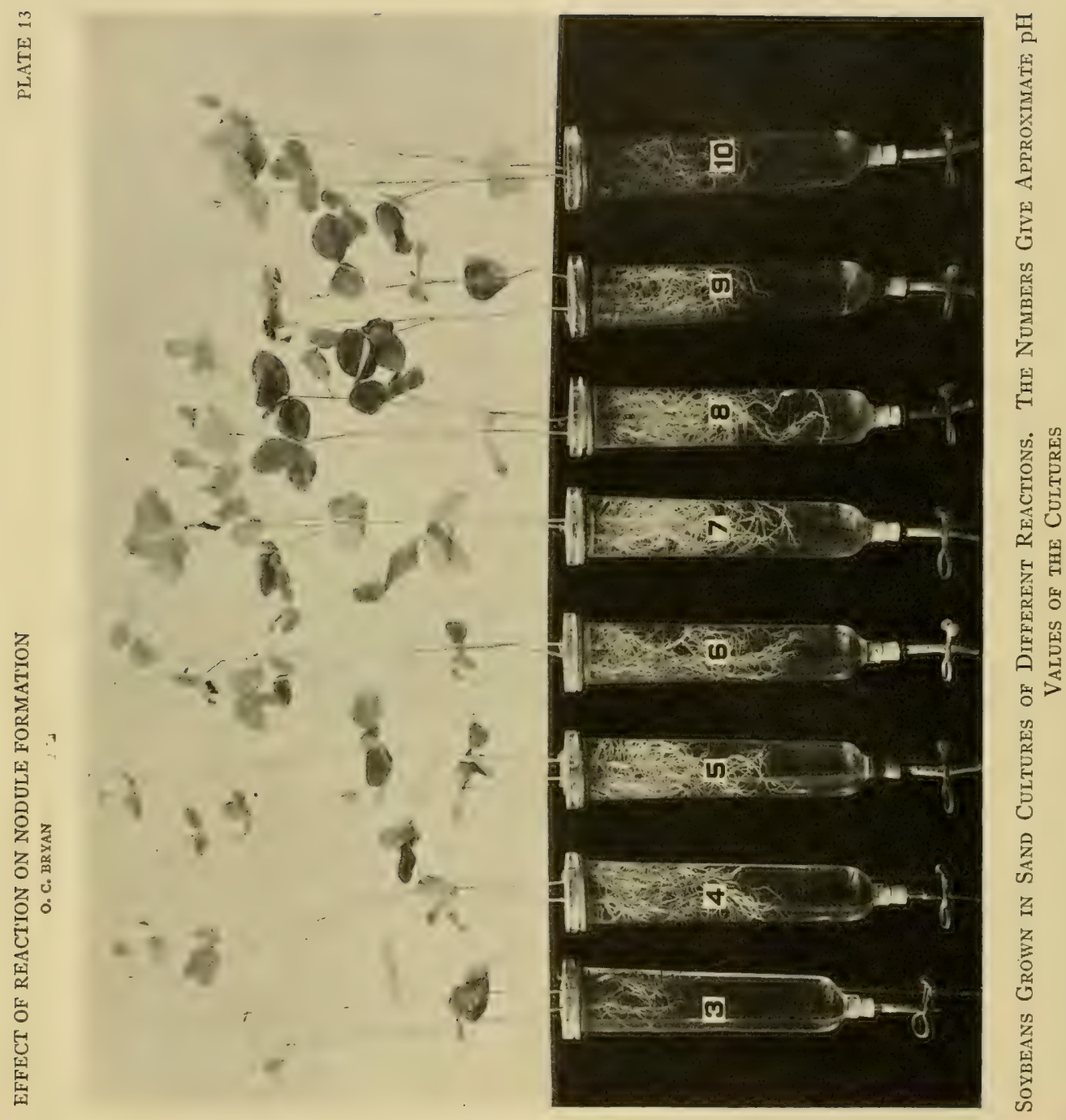



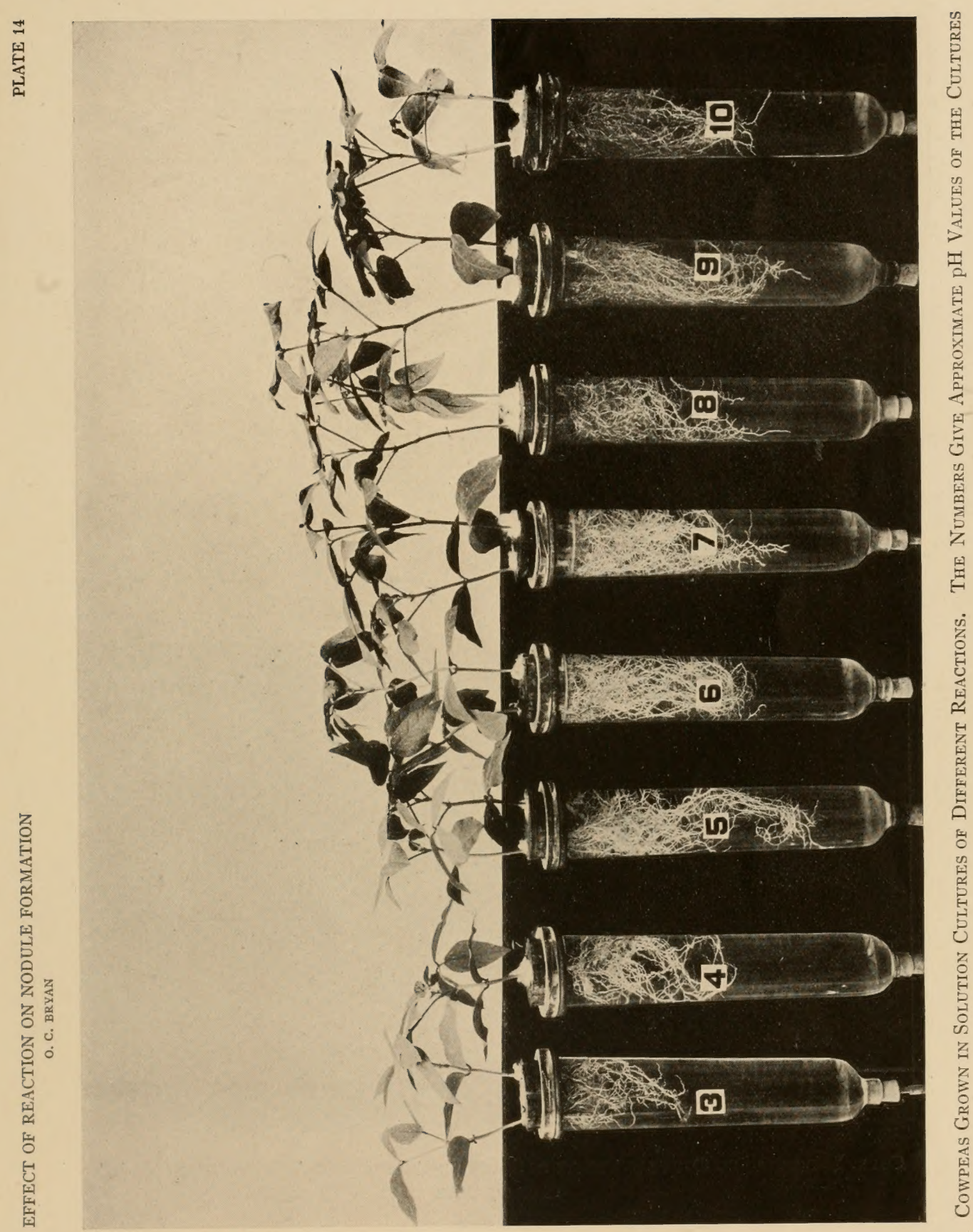


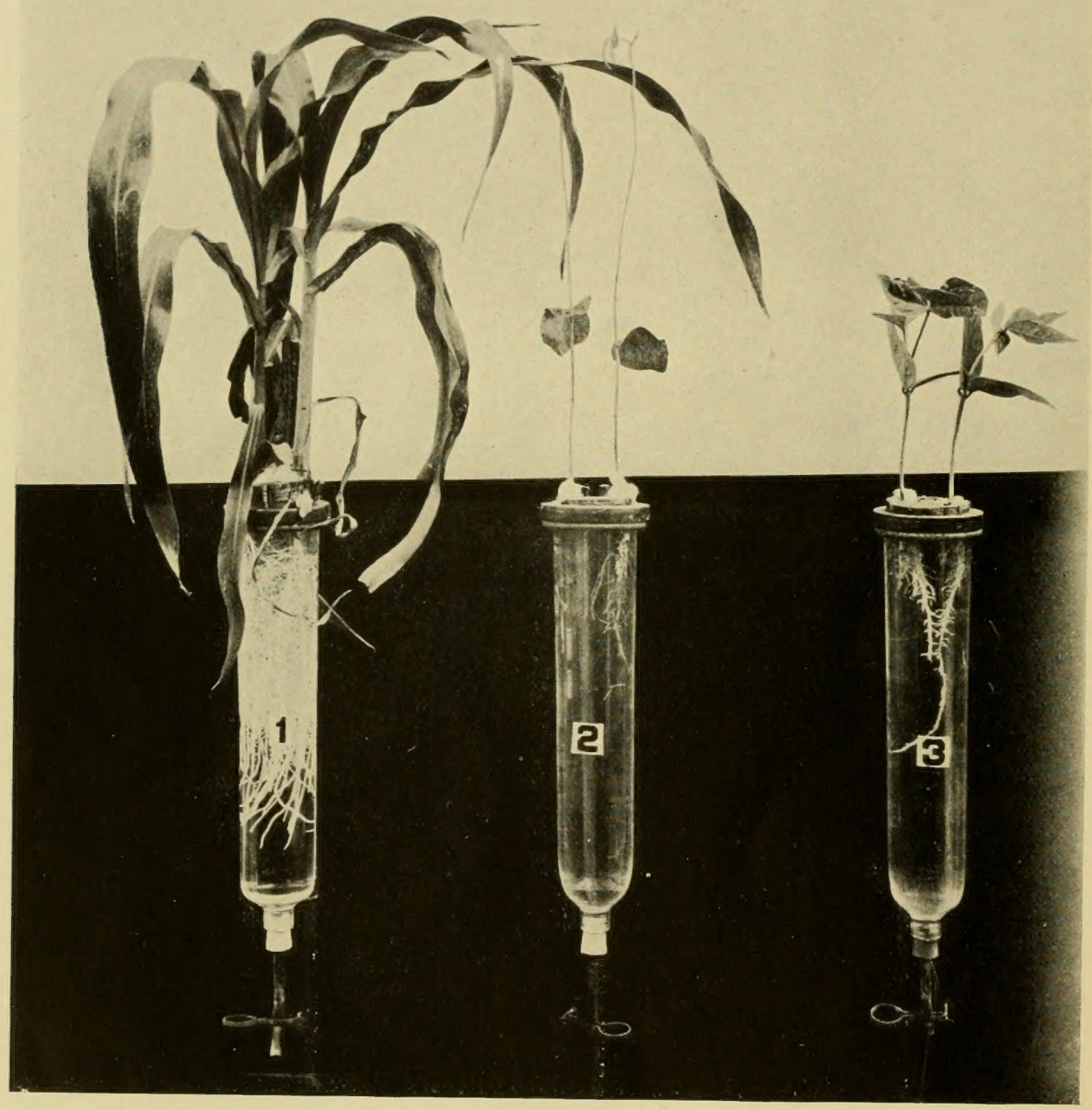

Corn, Soybeans and Cowpeas Grown in Solution Cultures of Approximately pH 4.0 IN EACH CASE 



\section{SOIL SCIENCE}

VOLUME 13, NUMBER 4, APRIL, 1922

\section{CONTENTS}

C. T. Hirst and J. E. Greaves. Factors Influencing the Determination of Sulfates in Soil.. 231

J. E. Greaves and E. G. Carter. The Influence of Moisture and Soluble Salts on the

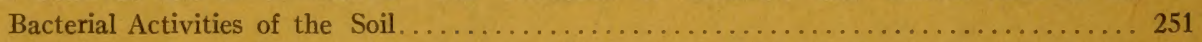

O. C. BRYAN. Effect of Different Reactions on the Growth and Nodule Formation of Soybeans. 271 Wiltiam M. Gibbs and C. H. Werkman. Effect of Tree Products on Bacteriological Activi-

ties in Soil: I. Ammonification and Nitrification.......................... 303 